\title{
Skin lesions in captive lemon sharks Negaprion brevirostris (Carcharhinidae) associated with the monogenean Neodermophthirius harkemai Price, 1963 (Microbothriidae)
}

\author{
Sarah L. Poynton ${ }^{1,2, *}$, Terry W. Campbell ${ }^{3, * *}$, Harry W. Palm ${ }^{2}$ \\ 'Division of Comparative Medicine, The Johns Hopkins University School of Medicine, Ross Building, 720 Rutland Avenue, \\ Baltimore, Maryland 21205, USA \\ ${ }^{2}$ Marine Pathology Group, Department of Fisheries Biology, Institut für Meereskunde an der Universität Kiel, \\ Düsternbrooker Weg 20, D-24105 Kiel, Germany \\ ${ }^{3}$ Animal Care, Sea World of Florida, 7007 Sea World Drive, Orlando, Florida 32821, USA
}

\begin{abstract}
Microbothriid monogeneans commonly infect the skin and gills of wild and captive requiem sharks (Carcharhinidae). We studied clinical signs and treatments for a microbothriid infection in 4 captive lemon sharks Negaprion brevirostris (Poey) from a large public aquarium (Sea World) in Florida, USA. Three adult sharks were held in a large exhibit tank with a variety of other elasmobranchs and teleosts, and one immature shark was held in a separate exhibit tank that shared this water. In 1994, there began a series of outbreaks of infections by the microbothriid Neodermophthirius harkemai Price, 1963 (possibly with secondary bacterial involvement), on the skin of the sharks. The infections were characterised by the sharks rubbing against the rocks and walls of the aquarium, by a dark band of hemorrhage and heavy mucus production around the mouth, and by irregular grey patches with excess mucus production on the skin, particularly on the head. Oral and parenteral administration of praziquantel was not effective, and trichlorofon treatment of the whole system was only partly effective, as were freshwater baths. In contrast, success was achieved by removing the sharks to an isolated facility and treating the water with copper sulphate $(0.25 \mathrm{ppm}$ for $85 \mathrm{~d})$; this removed the parasites, and the skin lesions were resolved. However, 2 mo after the recovered sharks were reintroduced into their original exhibit tank, the lesions on the skin and around the mouth recurred, strongly suggesting that a reservoir of parasites remained in the large exhibit tank. Novel aspects of microbothrid infection were the presence of $N$. harkemai as a serious pathogen on the skin, the dark band of hemorrhage around the sharks' mouths, and the successful use of copper sulfate to treat the infection
\end{abstract}

KEY WORDS: Microbothriid - Monogenean - Lemon shark - Captivity ' Aquarium - Lesions - Treatments - Copper sulphate

\section{INTRODUCTION}

Monogenean parasites commonly infect the body surfaces of wild elasmobranchs (Cheung et al. 1982, Cheung \& Nigrelli 1983, Cheung \& Ruggieri 1983,

•E-mail: spoynton@welchlink.welch.jhu.edu

- Present address: Zoological Medicine, Department of Clinical Sciences, College of Veterinary Medicine and Biomedical Sciences, Colorado State University, Fort Collins, Colorado 80523, USA
Cone 1995). In aquaria, infections are intensified, and microbothriid monogeneans may become problematic on requiem sharks (Carcharhinidae), leading to disease and death (Cheung et al. 1982, Cheung \& Nigrelli 1983, Cheung \& Ruggieri 1983, Cheung et al. 1988, Rand et al. 1986). Infections may be initially indicated by behavioral changes including erratic swimming, flashing and rubbing on the bottom of the tank (Cheung et al. 1982). Subsequently there are white or grey patches and ulcerated lesions on the skin, which 
become infected with bacteria (Cheung et al. 1982, Cheung \& Ruggieri 1983). Microbothriid infection in captive lemon sharks has been treated successfully with dylox (trichlorofon; 2,2,2,-trichloro-l-hydroxyethylphosphoric acid dimethyl ester; also called Masoten and Neguvon), and gentomycin and methyl green alcohol for the associated bacterial infection (Cheung et al. 1982).

In this report we describe the appearance and treatment of skin lesions in 4 captive lemon sharks Negaprion brevirostris (Poey) from Sea World of Florida, USA, associated with infection by a microbothriid. Since there may be differences in pathogenicity and susceptibility to treatments among monogeneans (Cone 1995), we followed the recommendations of Cone (1995), to identify the parasite to the species level. We now present several novel aspects of infection by, and treatment of, Neodermophthirius harkemai Price, 1963.

\section{MATERIALS AND METHODS}

Holding conditions for the sharks. Three adult lemon sharks were held in artificial sea water in a 25410001 ( 660000 gallon) exhibit tank at Sea World of Florida, where the water quality parameters between 1993 and 1996 were: temperature 24.5 to $25.5^{\circ} \mathrm{C}$; pH 8.0 to 8.4; and salinity 30 to 32 ppt. Shark A, a female, $272 \mathrm{~cm}$ in total length, was acquired in May 1988; shark B, a male, $272 \mathrm{~cm}$ in total length, was acquired in June 1990; and shark C, a male, $190 \mathrm{~cm}$ in total length, was acquired in January 1994. These sharks were housed with other elasmobranchs (brown sharks Carcharhinus plumbeus, bull sharks Carcharhinus leucas, nurse sharks Ginglymostoma cirratum, sandtiger sharks Eugomphodus taurus, and sawfish Pristis pectinata), and teleosts (giant grouper Epinephelus lanceolatus, leather grouper Epinephelus dermatolepis, jacks Caranx hippos, jewfish Epinephelus itajara, pompano Trachinotus carolinus, porkfish Anisotremus virginicus, and redfish Sciaenops occelatum). A fourth lemon shark, D, an immature female, $167 \mathrm{~cm}$ in total length, arrived in June 1990, and was held in a separate exhibit tank that shared the water with the larger exhibit tank. The lemon sharks were originally collected from the Florida Keys.

Identification of the parasite. Scrapings from skin and mouth lesions and from normal skin were collected when the sharks were occasionally manually restrained in vinyl stretchers. Live parasites harvested from the skin scrapings were examined under the binocular microscope to observe their morphology and motility. Whole mounts of the parasites were prepared by fixing worms in $10 \%$ formalin, staining with alcohol-carmine solution and mounting in Canada balsam.

\section{RESULTS}

\section{Case history and clinical signs}

The disease problem began in February 1994, 1 mo after the introduction of the last lemon shark, shark C, into the exhibit tank. This shark arrived from another aquarium, along with a sawfish and 5 giant grouper. Shark $C$ and the grouper were initially placed in quarantine and treated for $30 \mathrm{~d}$ with $0.25 \mathrm{ppm}$ copper sulphate, then put in the main exhibit tank. The sawfish was placed directly in the exhibit tank because it appeared stressed following transportation.

Between fall 1993 and fall 1995, the lemon sharks developed intermittent clinical signs of microbothriid infections, showing some or all of the following: rubbing on rocks and walls of the tank, a dark band of haemorrhagic skin around the mouth (Fig. 1), and irregular flat grey patches with haemorrhagic centers on the skin, particularly around the eyes and on the top of the head (Fig. 2). Skin lesions around the mouth and on the head were characterised by heavy mucus production, and many active microbothriids were seen (Fig. 2). Parasites were recovered from lesions on the heads of sharks $B$ and $C$ (Fig. 2), and from the mouth lesions on shark $D$; but not from infrequent scrapings from shark A, despite persistent worsening lesions. Parasites were not present in the scrapings of normal skin.

Despite recurring microbothriid infections, the 3 adult sharks from the main exhibit tank lived. Immature shark D died; gross necropsy and histopathology failed to identify the cause of death.

\section{Identification of the parasite}

The parasites had an elongate, tongue-shaped body, and a narrow elongate posterior end, terminating in an inconspicuous haptor. They swam very actively, with a rippling motion, and frequently the haptor stuck to the glass slide or cover slip. The stained whole parasites $(\mathrm{n}=6)$ (Fig. 3) were 2.0 to $5.0 \mathrm{~mm}$ long and 0.5 to $1.2 \mathrm{~mm}$ wide; the unusual haptor, characteristic for the family Microbothriidae, was very small and muscular, and lacked hooks, clamps, suckers, and septa; numerous testes (10 or 11 in 3 specimens) were characteristic of Neodermophthirius; other microbothrids have a single testis (Microbothrium), or a pair of testes (Dermophthirioides and Dermophthirius) (Cheung \& Nigrelli 1983, Hendrix 1994). The ovary was approximately rectangular, and situated anterior to the testes. The intestine was long, reaching to the posterior end of the vitellaria, and it had branched lateral diverticula. The morphology was consistent with Neodermophthirius harkemai, the only species in the genus, as originally described by Price (1963). 

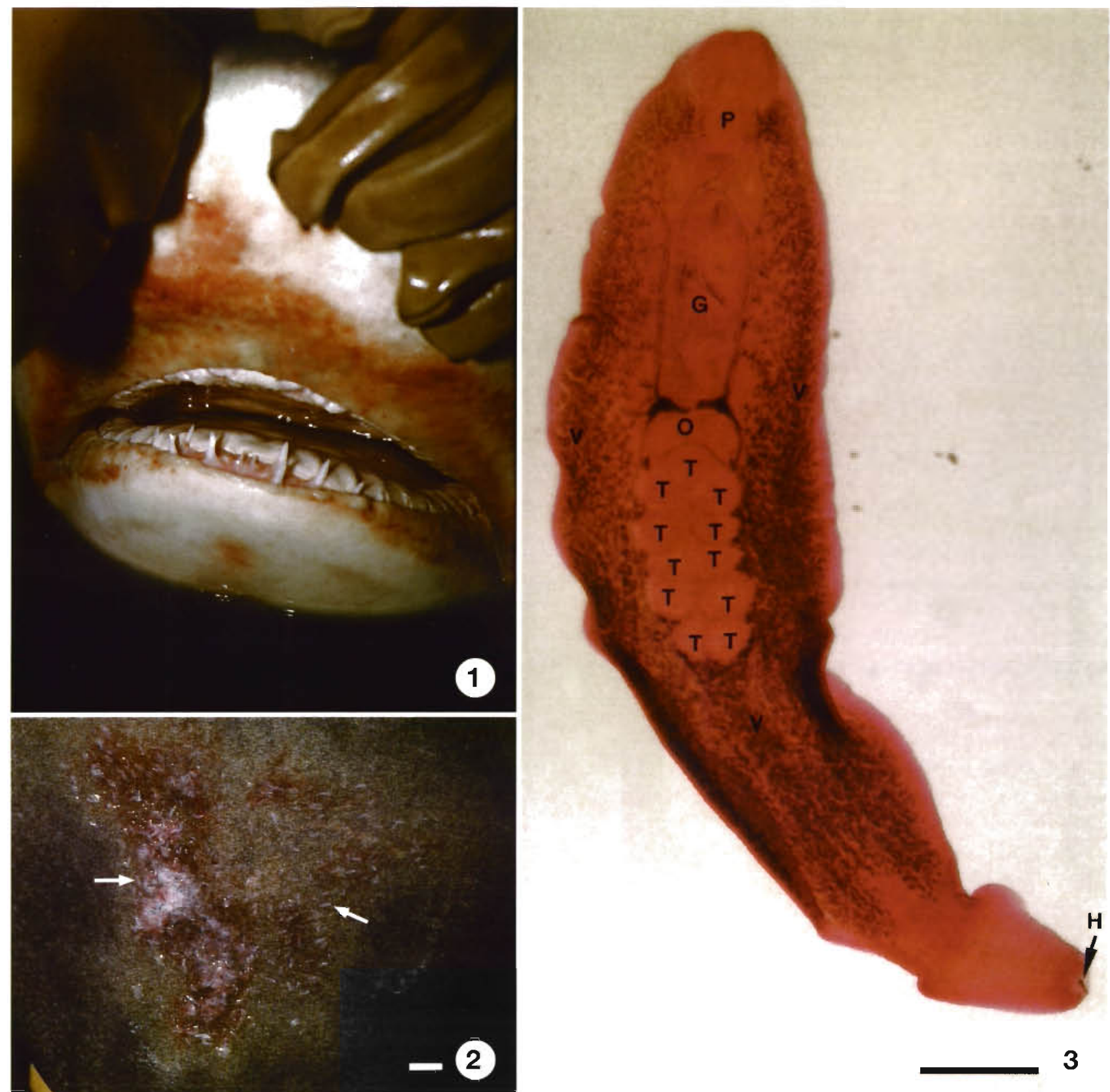

Figs. 1 to 3 . The monogenean Neodermophthirius harkemai infecting the lemon shark Negaprion brevirostris. Fig. 1. Mouth of the shark surrounded by an extensive haemorrhagic lesion. Fig. 2. Skin on the head of the shark showing the characteristic lesion, comprising an irregularly shaped grey patch. This contains extensive areas of haemorrhage and numerous active parasites (arrows). Scale bar $=1 \mathrm{~cm}$. Fig. 3. Whole mount of $N$. harkemai stained with carmine, showing the features used for identification: note that the haptor $(\mathrm{H})$, characterisitic for the family Microbothriidae, is small and muscular, and lacks hamuli (hooks), clamps, suckers and septa. The genus Neodermophthirius can be recognised by the high number of testes (T); in this specimen 11 are present. Other distinctive features are the genital complex (G), ovary (O), pharynx (P), and vitellaria (V) which coalesce posterior to the testes. The fine details of the genital complex, and the characteristic 8 finger-like papillae of the pharynx, are out of the plane of focus in this picture. Scale bar $=0.5 \mathrm{~mm}$

\section{Treatments}

Different treatments were given with varying degrees of success (Table 1). Initial treatments (praziquantel, trichlorofon, and freshwater dips) in the exhibit tanks were not completely successful. Oral and intramuscular praziquantel neither killed the parasites nor alleviated the lesions, although rubbing was sometimes reduced (this improvement was not related to dose of the drug). Treatment of the whole system with 
Table 1. Treatments administered to captive lemon sharks Negaprion brevirostris infected with the microbothriid Neodermophthirius harkema $i_{i}$ treatments are presented in chronological order

\begin{tabular}{|c|c|c|c|c|c|c|c|}
\hline Date & Treatment & Route & Dose & Frequency & Duration & Success & Shark \\
\hline Feb 1994 & Praziquantel $\mathrm{HCl}$ & Oral & $19.0 \mathrm{mg} \mathrm{kg}^{-1}$ & Daily & $3 \mathrm{~d}$ & No & $\mathrm{C}$ \\
\hline May/Jun 1994 & Praziquantel $\mathrm{HCl}$ & Oral & $8.0 \mathrm{mg} \mathrm{kg}^{-1}$ & Daily & $3 d$ & No & $\mathrm{C}$ \\
\hline Oct 1994 & Praziquantel $\mathrm{HCl}$ & Oral & $3.0 \mathrm{mg} \mathrm{kg}^{-1}$ & Alternate days & 4 treatments & No & $\mathrm{A}, \mathrm{B}, \mathrm{C}, \mathrm{D}$ \\
\hline Nov 1994 & Praziquantel $\mathrm{HCl}$ & Oral & $3.0 \mathrm{mg} \mathrm{kg}^{-1}$ & Daily & $3 d$ & No & $A, B, C, D$ \\
\hline Dec 1994 & Enrofloxacin & Oral & $5.0 \mathrm{mg} \mathrm{kg}^{-1}$ & Every $72 \mathrm{~h}$ & 7 treatments & (Antibacterial) & C \\
\hline Jan 1995 & Praziquantel $\mathrm{HCl}$ & Oral & $15.0 \mathrm{mg} \mathrm{kg}^{-1}$ & Alternate days & 3 treatments & No & $A, B, C$ \\
\hline Jan 1995 & Praziquantel $\mathrm{HCl}$ & $\operatorname{lm}$ & $7.5 \mathrm{mg} \mathrm{kg}^{-1}$ & Single dose & - & No & $\mathrm{D}$ \\
\hline Feb 1995 & Trichlor ofon $^{a}$ & Tank & $0.5 \mathrm{ppm}$ & Weekly & $3 w k$ & N.h. leaves fish & $\mathrm{A}, \mathrm{B}, \mathrm{C}, \mathrm{D}$ \\
\hline Mar 1995 & Praziquantel & Oral & $15.0 \mathrm{mg} \mathrm{kg}^{-1}$ & Daily & $3 \mathrm{~d}$ & No & \\
\hline Apr 1995 & Freshwater & Dip & - & Single & $30 \mathrm{~min}$ & Removes Nh. & $\mathrm{C}$ \\
\hline May 1995 & Freshwater & Dip & - & Single & $30 \mathrm{~min}$ & Removes $N h$. & $\mathrm{D}$ \\
\hline May 1995 & Copper sulfate & $T_{a n k}^{b}$ & $0.25 \mathrm{ppm}$ & Continuous & $85 \mathrm{~d}$ & Yes & $\mathrm{A}, \mathrm{B}, \mathrm{C}$ \\
\hline
\end{tabular}

trichlor of on did dislodge the parasites from the sharks, and numerous worms were found on the walls and rocks of the tank, but clinical signs persisted. Freshwater dips also dislodged the parasites. Shark $\mathrm{C}$ was also treated orally with enrofloxacin against opportunistic bacterial pathogens, but there was no improvement in the lesions.

Only removal of the adult sharks $A, B$, and $C$ to an isolated facility and subsequent treatment with copper sulfate $(0.25 \mathrm{ppm}$ for $85 \mathrm{~d}$ in the water) was successful. The parasites were removed, and normal skin returned without lesions. However, 2 mo after reintroduction into the exhibit tank, the lesions around the mouth and on the skin recurred, strongly suggesting that a reservoir of infection remained in the large exhibit tank.

\section{DISCUSSION}

\section{Pathology}

The present publication is the first report associating Neodermophthirius with disease in sharks, and the first report to indicate a dark band of haemorrhagic skin with heavy mucus production around the mouth as a possible clinical sign of microbothriid infection. Other clinical signs, such as rubbing and grey patches on the skin have previously been associated with Dermophthirius nigrelli and Dermophthirioides pristidus (Cheung et al. 1982, Cheung \& Nigrelli 1983). Disease onset, 1 mo after introduction of shark $C$ into the exhibit tank, is consistent with other reports of clinical signs appearing 1 to 3 mo after sharks enter the aquarium (Cheung et al. 1982, 1988, Cheung \& Nigrelli 1983, Cheung \& Ruggieri 1983).

It is likely that the clinical signs of Neodermophthirius harkemai infection are due to attachment and feed- ing of the parasite (Cheung et al. 1982, Cheung \& Ruggieri 1983, Rand et al. 1986), causing skin damage and irritation, prompting rubbing, and allowing establishment of secondary bacterial infections. Attachment of $N$. harkemai was probably facilitated by the sticky material on the haptor, which may be similar to the tyrosine-rich, membrane-bound lipoprotein that is believed to cement the haptor of Dermophthirius carcharhini to the host's scales (Rand et al. 1986). The frequent observation of microbothriids in the lesions, and the failure to find them on normal skin, strongly suggested that the parasites were responsible, at least in part, for the damage. We strongly suspect that secondary bacterial infections were present, possibly of the Vibrio-complex as have been presumptively identified as accompanying Dermophthirius infection in lemon sharks (Cheung et al. 1982). However we are unable to confirm this since bacteriology and histopathology were not routinely performed.

\section{The parasite}

The skin is reported as a new site of infection for $\mathrm{NeO}$ dermophthirius harkemai. Although this parasite has previously been reported from the gills of wild lemon sharks from North Carolina, USA, and Senegal, Africa (Price 1963, and Euzet \& Maillard 1967 respectively), it is likely that the skin is the usual site of infection, as is the case for most other microbothriids (Cheung 1993, Cone 1995). The skin was suggested as an additional site for this parasite by Euzet \& Maillard (1967), but not confirmed [in their report the parasite was described as Cadenatia polytestis, a species synonymous with $N$. harkemai according to Hendrix (1994)].

The abundance of Neodermophthirius harkemai on the lemon sharks, and its apparent absence from the 
other 5 elasmobranch species in the large aquarium, strongly suggests that this parasite has high host specificity, as has been reported for members of another microbothriid genus, Dermophthirius (Cheung et al 1988, Cone 1995).

Other reports of monogenea from lemon sharks include Dermophthirius nigrelli (Microbothriidae) from the skin of sharks collected along the Florida Keys and held in the New York Aquarium (Cheung \& Ruggieri 1983), Dermophthirius sp. (Microbothriidae) from the skin of a shark from the coast of Senegal (Euzet \& Maillard 1967), and Heterocotyle hypoprioni (Hexabothriidae) from the gills of a shark from Florida (Cheung 1993).

\section{Treatments and control of the infection}

In the present Neodermophthirius harkemai case, trichlorofon ( $0.5 \mathrm{ppm}$ once a week for $3 \mathrm{wk}$ ) dislodged the parasites from the sharks, but rubbing returned, and mouth lesions were not resolved. In contrast, trichlorofon $(0.5 \mathrm{ppm}$ with continuous exposure and 3 applications in 10 d) (Cheung et al. 1982) was sucessful against Dermophthirius sp. in captive lemon sharks. These differences in efficacy may indicate that the more intense dosage is necessary, and Neodermophthirius spp. and Dermophthirius spp. may also vary in their tolerance of and response to therapeutic agents. Thus, it becomes increasingly important to undertake accurate and detailed identification of the parasites, in order to facilitate the choice of the most appropriate treatments.

The successful use of copper sulfate $(0.25 \mathrm{ppm}$ continuously for $85 \mathrm{~d}$ ) offers a further treatment option for microbothriid infections in elasmobranchs, in addition to the use of dylox (trichlorofon) advocated by Cheung et al. (1982). Although treatment with copper sulphate in the isolated facility was effective, clinical signs recurred 2 mo after the lemon sharks were returned to their normal exhibit tank, raising the possibility that some parasites may have been retained during the copper sulphate treatment. We believe, however, that a more likely explanation for the recurrence of infection is that a reservoir of parasites remained in the large exhibit tank, and these parasites reinfected the reintroduced lemon sharks. It is unlikely that the other elasmobranchs or teleosts served as reservoirs of infection, since these fish did not show clinical signs of infection by Neodermophthirius harkemai, consistent with the narrow host specificity of microbothriids. Thus we propose that the monogeneans forming the reservoir of infection were able to survive in the large exhibit tank, as adults and or eggs, without their preferred hosts, for at least a 2 mo period.
The original introduction of the infection into the main exhibit tank may have been parasites that survived on shark $C$, despite its initial $30 \mathrm{~d}$ quarantine treatment with $0.25 \mathrm{ppm}$ copper sulphate. Prior to arrival at Sea World of Florida, shark $C$ had been held in another aquarium for $4 \mathrm{mo}$, following capture from the wild in September 1993. It is possible that the sawfish Pristis pectinata that was transported with shark C was a carrier for Neodermophthirius harkemai, since this fish was placed immediately into the exhibit tank following transport, without quarantine treatments.

Acknowledgements. We extend our sincere thanks to Dr George Benz of the Tennessee Aquarium, Chattanooga, TN USA, and to Dr Paul Cheung of the Aquarium for Wildlife Conservation, Brooklyn, NY, for their kindness in confirming the identity of the parasite, and for their help with provision of literature. We also thank Mr Ray Davis, Assistant Curator of Fish at Sea World of Florida, for loaning us the photographs of the lesions on the lemon sharks. We are grateful to Dr Tracie Bunton of Johns Hopkins University School of Medicine, Baltimore, for her constructive review of the manuscript.

\section{LITERATURE CITED}

Cheung PJ (1993) Parasitic diseases of elasmobranchs. In Stoskopf MK (ed) Fish medicine. WB Saunders, Philadelphia, p 782-807

Cheung PJ, Nigrelli RF (1983) Dermophthirioides pristidis n.gen., n.sp. (Microbothriidae) from the skin and Neoheterocotyle ruggierii n.sp. (Monocotylidae) from the gills of the smalltooth sawfish, Pristis pectinata. Trans Am Microsc Soc 102:366-370

Cheung PJ, Nigrelli RF, Ruggieri GD, Cilia A (1982) Treatment of skin lesions in captive lemon sharks, Negaprion brevirostris (Poey), caused by monogeneans (Dermophthirius sp.). J Fish Dis 5:167-170

Cheung PJ, Nigrelli RF, Ruggieri GD, Crow GL (1988) A new microbothriid (monogenean) causing skin lesions on the Pacific blacktip reef shark, Carcharinus melanopterus (Quoy and Gaimard). J Aquaric Aquat Sci 5:21-25

Cheung PJ, Ruggieri GD (1983) Dermophthirius nigrellii n.sp. (Monogenea: Microbothriidae), an ectoparasite from the skin of the lemon shark, Negaprion brevirostris. Trans Am Microsc Soc 102:129-134

Cone DK (1995) Monogenea (Phylum Platyhelminthes). In: Woo PTK (ed) Fish diseases and disorders, Vol 1, Protozoan and metazoan infections. CAB International, Wallingford, p 289-327

Euzet L، Maillard C (1967) Parasites des poissons de mer ouest-africains, récoltés par J. Cadenat. VI. Monogenes de Selaciens. Bull Inst Fondam Afr Noire Ser A Sci Nat XXIX: $1435-1493$

Hendrix SS (1994) Marine flora and fauna of the eastern United States. Platyhelminthes: Monogenea. NOAA Tech Rep NMFS 121

Price EW (1963) A new genus and species of monogenetic trematode from a shark, with a review of the family Microbothriidae Price, 1936. Proc Helminthol Soc Wash 30: $213-218$

Rand TG, Wiles M, Odense P (1986) Attachment of Dermophthirius carcharhini (Monogenea: Microbothriidae) to the Galapagos shark Carcharhinus galapagensis. Trans Am Microsc Soc 105:158-169

Submitted: December 30, 1996; Accepted: June 30, 1997

Proofs received from author(s): September 29, 1997 